University of Pennsylvania Carey Law School

Penn Law: Legal Scholarship Repository

Faculty Scholarship at Penn Law

1999

\title{
The Medium is the Mistake: The Law of Software for the First Amendment
}

\author{
R. Polk Wagner \\ University of Pennsylvania Carey Law School
}

Follow this and additional works at: https://scholarship.law.upenn.edu/faculty_scholarship

Part of the Computer Law Commons, Constitutional Law Commons, Engineering Commons, First Amendment Commons, Jurisprudence Commons, Science and Technology Law Commons, and the Software Engineering Commons

\section{Repository Citation}

Wagner, R. Polk, "The Medium is the Mistake: The Law of Software for the First Amendment" (1999). Faculty Scholarship at Penn Law. 1279.

https://scholarship.law.upenn.edu/faculty_scholarship/1279

This Article is brought to you for free and open access by Penn Law: Legal Scholarship Repository. It has been accepted for inclusion in Faculty Scholarship at Penn Law by an authorized administrator of Penn Law: Legal Scholarship Repository. For more information, please contact PennlawIR@law.upenn.edu. 


\title{
The Medium is the Mistake: The Law of Software for the First Amendment
}

\author{
R. Polk Wagner*
}

Is computer software - code written by humans that instructs a computer to perform certain tasks-protected by the First dmendment? The answer to this question will significantly impact the course of future technological regulation and will affect the scope of free expression rights in new media. In this note. $R$. Polk Wagner sets forth a framework for analysis of this issue, noting at the outset that the truly important question in this context is the threshold question. What is "speech or. the press"? Wagner first describes two ways that the Supreme Court has addressed the threshold question. One is ontological focusing on the expressive content of the speaker's conduct or the medium chosen. The second approach is teleological - determining whether the regulation at issue implicates free expression. Wagner argues that the teleological mode-especially as applied to computer software and other new media-is the more likely to be consistently speech-protective, and that the courts that have addressed computer soffware have mistakenly opted for the ontological, medium-focused analysis. Use of a teleological approach implies that there should be no "law of software," a conclusion that Wagner argues holds the most promise for extending robust First Amendment protections into new mediums of communication.

Each method of communicating ideas is "a law unto itself" and that law must reflect the "differing natures, values, abuses and dangers" of each method.

- Metromedia, Inc, v. San Diego ${ }^{1}$

There's truth in the old saw that familiarity breeds contempt: nobody goes to Speakers Corner to listen.

- John Hart Ely

* J.D., Stanford Law School, 1998; B.S.E., University of Michigan, 1993. The author wishes to extend thanks to Professors John Hart Ely, Tom Grey, Margaret Jane Radin, and Kathleen Sullivan, to the participants in the Legal Studies Colloquium at Stanford Law School for helpful comments and suggestions, and to Paul Epstein and Tyler Newby of the Stanford Law Review for their editing. Their assistance greatly strengthened this paper; its remaining weaknesses are mine alone.

1. 453 U.S. 490, 501 (1981) (quoting Kovacs v. Cooper, 336 U.S. 77, 97 (1949) (Jackson, J., concurring)).

2. John Hart Ely, Flag Desecration: A Case Study in the Roles of Categorization and Balancing in First Amendment Analysis, 88 HARV. L. REV. 1482, 1489 (1975). 
It is Saturday, somewhere in Silicon Valley. Debra, a young computer programmer, is putting the finishing touches on a revolutionary new software product, Lucifer. ${ }^{3}$ Written in the programming language known as Java ${ }^{\mathrm{T} M}$, Debra intends to make Lucifer available to computer users on a variety of popular platforms. An experienced programmer, she understands that programming is a curious mixture of science and art, the pragmatic and the elegant. There is much original thought built into Debra's program, such as her ideas about proper logical organization, or the best language in which to program. But her creativity is highly constrained by the very fact that she is writing a set of instructions to drive a machine. In fact, in order to make the program useful, she must convert the Java code she understands into a language that the machine's processor understands - a process known as compilation. Once compilation is complete, the software can be used to operate a computer in the way in which she intended.

Debra's intent in writing Lucifer is complex. Lucifer is designed to break into - "hack"- - corporate and government computer systems. Debra knows that hacking is against the law, ${ }^{4}$ but she persists nonetheless for several reasons. First, she believes that the laws against hacking are misguided, serving only to lull corporations and governments into a false sense of security about the invulnerability of their networks. Additionally, she hopes to share her ideas about programming by letting other programmers see and use her work, ${ }^{5}$ Finally, Debra hopes to make money by marketing Lucifer software to corporations and governments as a tool for analyzing the strength of their security systems. ${ }^{6}$

Can Debra be prosecuted under a law making it illegal to develop hacking software? Or does Lucifer raise First Amendment questions, limiting the power of government to stop Debra's programming and distribution activities? Hacking is conduct, but programming is at least partially expression. And Debra's creation of Lucifer clearly has expressive motivations, just as

3. Both Lucifer and Debra are fictional, though their story is inspired by the program called "Satan" written by software programmers Wietse Venema and Dan Farmer. See John Markoff, Dismissal of Security Expert Adds Fuel to Internet Debate, N.Y. Times, Mar. 22, 1995, at D4 (describing "Satan" and its writers' plans for its release).

4. See generally Xan Raskin \& Jeannie Schaldach-Paiva, Computer Crimes, 33 AM. CRIM. L. REV, 541 (1996) (surveying different types of computer crime). Every state except Vermont has enacted some form of computer-crime statute. See id at $563 \& \mathrm{n} .153$.

5. Cf. Whitney v. California, 274 U.S. 357, 375 (1927) (Brandeis, J., concurring) ("[F]reedom to think as you will and speak as you think are means indispensable to the discovery and spread of political truth.").

6. Cf. United States v. National Treasury Employees Union, 513 U.S. 454, 468 (1995) (holding that a "prohibition on compensation unquestionably imposes a significant burden on expressive activity"). 
Gregory Lee Johnson made his point by burning a flag in Dallas. ${ }^{7}$ But does the programming of Lucifer itself - writing the computer software or codefall within "speech" or the "press" as did Johnson's activity? First Amendment doctrine "has often faced the problem of applying the broad principles of the First Amendment to unique forums of expression."

The First Amendment generally forbids laws "abridging the freedom of speech, or of the press." 10 While the courts and commentators have spared little ink in providing content to the limits of government activity with respect to speech and the press, they have paid considerably less attention to a logically anterior question: What is it, exactly, that "bring[s] the First Amendment into play?"11

When the forum of communication involved is the spoken or written word, courts and commentators do not linger long on this question. ${ }^{12}$ Called "relatively minor First Amendment doctrine,"13 the threshold question may seem but a smallish bump on the road to substantive First Amendment analysis-a procedural footnote to the grand tenets of "time, place, and manner" or "balancing tests." 14 Further, even when the threshold question is considered, it is often read as an epithet announcing a result rather than as the product of careful analysis. ${ }^{15}$

However, the threshold question-determining what is speech or the press -is critically important. A complete First Amendment analysis re-

7. See Texas v. Johnson, 491 U.S. 397, 420 (1989) (striking down conviction under a state flag desecration law).

8. U.S. CONST, amend. I ("Congress shall make no law ... abridging the freedom of speech, or of the press ....").

9. Metromedia, Inc. v. San Diego, 453 U.S. 490, 500 (1981).

10. U.S. CONST. amend. I.

11. Johnson, 491 U.S. at 404.

12. See, e.g., New York Times Co. v. Sullivan, 376 U.S. 254, 265-66 (1964) (applying First Amendment standards to an "editorial advertisement" published in a newspaper). See generally Laurence H. Tribe, American Constitutional Law 789-94 (1988) (discussing two "tracks" of First Amendment analysis). But see Hurley v. Irish-American Gay, Lesbian and Bisexual Group, 515 U.S. 557, 568-70 (1995) (finding that a parade was a form of protected expression); Barnes v. Glen Theatre, Inc., 501 U.S. 560, 565-66 (1991) ("[N]ude dancing . . . is expressive conduct within the outer perimeters of the First Amendment."); Spence v. Washington, 418 U.S. 405, 406, 409-10 (1974) (per curiam) (stating that affixing a peace symbol to a flag was a form of communication). (1995).

13. Robert Post, Recuperating First Amendment Doctrine, 47 STAN. L. REv. 1249, 1252

14. See, e.g., id. at 1260-70 (discussing the time, place, and manner test).

15. See, e.g., United States v. O'Brien, 391 U.S. 367, 376 (1968) (assuming First Amendment protection for draft card burning in holding that the government's interest in restricting it was justified under the Constitution). Professor Tribe notes that "the distinction between speech and conduct must be seen at best as announcing a conclusion of the Court, rather than as summarizing in any way the analytic processes which led the Court to that conclusion." TRIBE, supra note 12, at 827. 
quires three generalized steps. First is the threshold question: Is freedom of speech and the press implicated? If so, the analysis moves to the second step: What is the level of scrutiny to be applied to the government action at issue? Once the court answers this question, the third step controls: Does the justification for the regulation meet the scrutiny imposed? In effect, any one of these steps may be dispositive. Laws that do not implicate the First Amendment do not receive First Amendment review.16 A "strict scrutiny" standard, in most cases, will be the death knell for the regulation at issue. ${ }^{17}$ And even if it does not fully resolve the issue, the threshold question affects governmental activities by determining whether content-neutral justifications must be made for the regulation. ${ }^{18}$

The threshold issue typically attracts attention when new modes of communication are used - and regulated. Union picketers are charged under a state antipicketing law. ${ }^{19}$ A young man burns his draft card, ${ }^{20}$ defaces the American flag, ${ }^{21}$ or burns it.22 The development and expansion of technology in particular raises the threshold question. Computer programmers attempt to export encryption software code; ${ }^{23}$ our Debra and her Lucifer software raise similar questions about what qualifies as speech.

This note investigates the operation of the First Amendment threshold test in an effort to determine the "law of software." Part I identifies two separate methods of threshold analysis employed by the Supreme Court:

16. See, eg., Barnes, 501 U.S. at 578 (Scalia, J., concurring) (explaining the limitations of First Amendment applicability); Arcara v. Cloud Books, Inc., 478 U.S. 697, 707 (1986) (holding that a statute permitting the closure of a bookstore where solicitation of prostitution took place did not implicate the First Amendment).

17. See, e.g., R.A.V. v. St. Paul, 505 U.S, 377, $395-96$ (1992) (holding that a "hate crime" ordinance prohibiting the display of a symbol calculated to arouse anger on the basis of race was not narrowly tailored - and therefore constitutionally invalid - because it was content-specific); Spence, 418 U.S. at $411-15$ (1974) (per curiam) (finding that affixing a peace symbol to a flag did not significantly impair the state's interest in preserving the flag's physical integrity).

18. Compare Arcara, 478 U.S. at 706-07 (declining to apply First Amendment principles to "a public health regulation of general application"), with Clark v. Community for Creative NonViolence, 468 U.S. 288 (1984) (allowing the government to prevent camping in a park for contentneutral reasons). One suspects that the resolution of the threshold question will determine, at the very least, whether the case is resolved in pretrial motions or at trial. See, e.g., GERALD GUNTHER \& KATHLEEN M. SUlLivan, CONSTITUTIONAL LAW 1210 (13th ed. 1997) (discussing the difference in scrutiny between content-neutral and content-based regulations).

19. See Thomhill v. Alabama, 310 U.S. 88 (1940) (declaring that peaceful picketing is speech).

20. See O'Brien, 391 U.S. at 369.

21. See Spence, 418 U.S at 405.

22. See Texas v. Johnson, 491 U.S. 397 (1989).

23. See, e.g., Bernstein v. United States Dep't of State, 922 F. Supp. 1426, 1429-30, I436 (N.D. Cal 1996) (holding that computer source code is speech protected by the First Amendment); Karn v. United States Dep't of State, 925 F. Supp. I, 3-4 (D.D.C. 1996) (holding that export restrictions on cryptographic source code did not violate the First Amendment). 
ontological and teleological. ${ }^{2+}$ The ontological mode-also properly referred to as "mode-specifie"-looks to the activities of the speaker as a guide to whether free expression is implicated. If the speaker is "speaking," then the First Amendment is triggered..$^{25}$ The ontological analysis encompasses more than the speech-conduct distinction, however. The Supreme Court also uses the medium of communication chosen by the speaker as the basis for the threshold determination. ${ }^{26}$ The teleological mode, on the other hand, makes no reference to the speaker's activities or choice of medium. Instead, it focuses squarely on whether the governmental interests that support the regulation are related to the suppression of free expression. ${ }^{27}$ If these interests are not related to free expression, then the analysis is complete; the First Amendment is not implicated.

Part II analyzes the law of software as applied to this threshold framework. The teleological mode, of course, rejects any categorization of mediums, and thus lends no guidance to (or support for) a law of software. However, application of the ontological approach to the particularities of computer software exposes fundamental weaknesses in the mode of analysis, leading to a questioning of this approach, at least as applied to new media. A threshold focus on the mode of communication--the expressive content of the speaker's activities or the medium in which they are conducted-is unlikely to provide strong protection for First Amendment values in the new

24. These terms were originally employed by Professor Ely in a similar context. See Ely, supra note 2, at 1496.

25. See Johnson, 491 U.S. at 403-06; see also Spence, 418 U.S, at 409-11.

26. See Hurley v. Irish-American Gay Lesbian and Bisexual Group, 515 U.S. 557, 568 (1995) (finding that a public parade is a "form of expression"); Barnes v. Glen Theatre, Inc., 501 U.S. 560 , 565-67 (1991) (holding that nude dancing gets some First Amendment protection); Ward v. Rock Against Racism, 491 U.S. 781, 790 (1989) ("[M]usic, as a form of expression and communication, is protected under the First Amendment."); Murdock v. Pennsylvania, 319 U.S. 105, 108-12 (1943) (approving First Amendment protection for the sale of religious handbills); cf. Winter v. G.P. Putnam's Sons, 938 F.2d 1033, 1035 (9th Cir. 1991) (stating that a guide to mushrooms "is pure thought and expression" not covered by state products liability laws); City of Dallas v. Stanglin, 490 U.S. 19, 25 (1989) (finding that a gathering for recreational dancing is not "expressive association").

27. See R.A.V. v. St. Paul, 505 U.S. 377, 393-96 (1992) (holding that a city ordinance prohibiting incendiary speech toward racial groups was unconstitutional because it selectively prevented the expression of particular ideas); Cohen v. Cowles Media Co., 501 U.S. 663, 669-70 (1991) (holding that promissory estoppel was a law of general application that did not single out the press); Barnes, 501 U.S. at $577-79$ (Scalia, J., concurring) ("[T]he only First Amendment analysis applicable to laws that do not directly or indirectly impede speech is the threshold inquiry of whether the purpose of the law is to suppress communication.") (quoting Community for Creative Non-Violence v. Watt, 703 F.2d 586, 622-23 (D.C. Cir. 1983) (en banc) (Scalia, J., dissenting)); see also United States v. Eichman, 496 U.S. 310, 315-18 (1990) (striking down the federal Flag Protection Act because the government interest was related to the suppression of free expression); Arcara v. Cloud Books, Inc., 478 U.S. 697, $702-07$ (1986) (finding that a statute permitting the closure of places in which prostitution was solicited was not aimed at limiting expressive activity). 
media context. This note concludes that the teleological approach, though imperfect, may be better suited to the developing technology of new media communications. That is, for First Amendment threshold purposes, the "law of software" simply should not exist.

\section{From Ontology to Teleology: THE Modes of Threshold ANALYSIS}

Lest any readers have lingering suspicions about the existence of a First Amendment threshold question, this part will address that issue before moving further. The underlying logic of this point is that courts can uphold regulations alleged to be prohibited by the First Amendment "on the ground that they need not be evaluated according to First Amendment standards," and they can uphold the very same regulations because they "withstand constitutional scrutiny." ${ }^{28}$ Therefore, some sort of boundary criteria must be established to determine whether First Amendment standards will be brought to bear. The Supreme Court has repeatedly recognized this threshold determination, both expressly and implicitly. In Spence v. Washington, ${ }^{29}$ the Court noted as an initial matter that "[i]t is therefore necessary to determine whether [Spence's] activity was sufficiently imbued with elements of communication to fall within the scope of the First and Fourteenth Amendments. ${ }^{30}$ In Clark v. Community for Creative Non-Violence, ${ }^{31}$ the Court noted that the determination (or assumption) of whether "expressive conduct" is present "begins the inquiry." "32 In Arcara v. Cloud Books, ${ }^{33}$ the Court dismissed First Amendment concerns, concluding that "the First Amendment is not implicated by the enforcement of a public health regulation of general application. ${ }^{.34}$

That the threshold question is not always explicitly answered by the Court $^{35}$ does not mean that it does not exist. Where a set of facts concededly implicates speech or the press, there is obviously little need to linger on the

28. Post, supra note 13 , at 1250.

29. 418 U.S. 405 (1974) (per curiam).

30. Id. at 409 .

31. 468 U.S. 288 (1984).

32. Id. at 293.

33. 478 U.S. 697 (1986).

34. Id. at 707 .

35. In fact, the threshold question is rarely - too rarely in the author's view-addressed. 
issue. ${ }^{36}$ In Texas $v$, Joinson, ${ }^{37}$ the Court noted that the fact that Johnson was not convicted for uttering words "somewhat complicates [the] considerathon" 38 of the First Amendment issues, by requiring that the Court "first determine" whether the case implicated the First Amendment at all,,$^{39}$ Plainly, it is only where the threshold question matters - where one side or the other chooses to make it an issue - that the analysis is undertaken.

Here we deal with computer software, a situation where, as we shall see, the threshold question does matter..$^{10}$

\section{A. Ontological Threshold Analysis}

When the Court does ask the threshold question, one method by which it approaches the issue is ontologically. That is, it looks to the purported speaker's activities to determine whether they possess sufficient communicative elements to bring the First Amendment into play. The most recognizable version of this mode of analysis is the Court's speech-conduct distinction first hinted at in United States v. $O^{\prime}$ Brien, ${ }^{41}$ given content in Spence v. Washington, and reaffirmed in Texas v, Johnson.

The crux of the speech-conduct distinction is that while "speech" is highly protected, "conduct" is not. ${ }^{42}$ The task of courts under this rubric is

36. Paradigmatic cases here include those that explicitly bear on speech or the press, the spoken or written word. See, e.g., Minneapolis Star \& Tribune Co. v. Minnesota Comm'r of Revenue, 460 U.S. 575 (1983) (striking down, on First Amendment grounds, a tax directed at newspapers); New York Times Co. v. Sullivan, 376 U S. 254 (1964) (addressing libel laws directed at newspapers)

37. 491 U.S. 397 (1989).

38. Id. at 402-03 (1989).

39. Id.

40. Of course, it is possible to argue that since computer software code can be printed out, software is clearly "speech" or "press," obviating the need for threshold analysis. For example, the District Court for the Northern District of California, in Bernstein v. United States Department of State, 922 F. Supp. 1426 (N.D. Cal, 1996), came close to stating this argument. The District Court noted that, because the plaintiff's "encryption system is written, albeit in computer language rather than in English," expressiveness of conduct need not be considered. Id. at 1434-35. But rather than obviating the threshold question, the District Court was choosing a particular form of the ontological mode of threshold analysis. That is, instead of evaluating the speaker's conduct, the court evaluated the speaker's choice of medium. Because software code could be printed out (or "written"), it was thus evaluated to be speech. See id.

41. 391 U.S. 367 (1968). In this case, the majority stated that "we cannot accept the view that an apparently limitless variety of conduct can be labeled 'speeeh' whenever the person engaging in the conduct intends thereby to express an idea." Id. at 376. But as Professor Ely noted, this statement was a "false lead" to the true holding of the O'Brien Court, which moved on to focus on the interests of the regulation as the threshold question. See Ely, supra note 2, at 1494-96 (citing O'Brien, 391 U.S. at 377 ).

42. See Johnson, 491 U.S. at 406 ("[T]he government generally has a freer hand in restricting expressive conduct than it has in restricting the written or spoken word."). 
"to determine whether [the speaker's] activity was sufficiently imbued with elements of conmunication" to trigger the protections of the First Amendment. ${ }^{43}$ In making this determination, the Court has asked whether (1) "[a]n intent to convey a particularized message was present," and (2) "the likelihood was great that the message would be understood by those who viewed it." "It If both elements are present, then the Court will apply First Amendment analysis. ${ }^{+5}$

Unfortunately, fundamental fallacies underlie the speech-conduct dichotomy. It simply cannot be disputed that "[t]o some extent expression and action are always mingled; most conduct includes elements of both." 46 In fact, as Professor Ely has pointed out: "[B]urning a draft card to express opposition to the draft is an undifferentiated whole, $100 \%$ action and $100 \%$ expression. It involves no conduct that is not at the same time communication, and no communication that does not result from conduct," 47

Moreover, the test is quite difficult to administer in practice; it is not at all clear where on the spectrum of speech versus conduct a particular activity may fall. While I cannot be prevented from publicly speaking or writing "Wagner for Congress," blasting the same on loudspeakers at three in the morning may be regulated. ${ }^{48}$ Indeed, by the terms of Spence, a flag burning defendant would have as strong a claim to First Amendment protection as one who defaced public property with written graffiti, if not stronger ${ }^{49}$ This

43. Spence v. Washington, 418 U.S. 405.409 (1974) (per curiam).

44. Johnson, 491 U.S. at 404 (quoting Spence, 418 U.S. at $410-11$ ).

45. See, e.g, Spence, 418 U.S, at 415 (finding that displaying a flag with a peace symbol conveyed a particular message "likely to be understood, and within the contours of the First Amendment"); Johmson, 491 U.S. at 406 (finding that in burning a flag, Johnsen's expression was "both intentional and overwhelmingly apparent"). This analysis does not always involve heightened scrutiny.

46. ThOMAS I EMERSON, THE SYSTEM OF FREedOM OF EXPRESSION 80 (1970). "Moreover, if the expression involves talk, it may be noisy; if written, it may become litter." TRIBE, supra note 12, at 827 (citing Kovacs v. Cooper, 336 U.S. 77 (1949) (upholding an ordinance prohibiting the use of sound trucks on public streets) and Schneider v, Irvington, 308 U.S. 147 (1939) (upholding an ordinance barring the distribution of leaflets as a means of reducing litter)).

47. Ely, supra note 2, at 1495. The Court appears to have tried to rectify the speech-conduct distinction by noting that its importance is substantive rather than procedural. The government "may not ... proscribe particular conduct because it has expressive elements." Johnson, 491 U.S. at 406. But the fact remains that expression and action are an "undifferentiated whole .... and to outlaw the act is therefore necessarily to regulate both [the active and expressive] elements." Ely, supra note 2 , at 1496.

48. See, e.g., Kovacs v. Cooper, 336 U.S. 77, 89 (1949 (allowing restrictions on "loud and raucous" sound trucks).

49. Under Spence, the flag burner would have to show that the "context in which [the flag was burned] for purposes of expression" was such that those who viewed it would be likely to understand the message. Spence, 418 U.S. at 410 . A defacer could obviate this prong of the analysis by, for example, spray-painting "Impeach Clinton." 
analysis is also clearly subject to problems of characterization, as conduct "cannot be labeled 'speech' whenever the person engaging in the conduct intends thereby to express an idea." 50

The Court appeared to drop the speech-conduct distinction after Spence, resurrecting it only in Texas $v$. Johnson fifteen years later. ${ }^{51}$ More recently, the Court criticized the first factor (the "particularized message" requirement) of the Spence framework in Hurley v. Irish-American Gay, Lesbian and Bisexual Group. Jiz Justice Souter spoke for a unanimous court when he stated that "a narrow, succinctly articulable message is not a condition of constitutional protection, which if confined to expressions conveying a 'particularized message,' would never reach the unquestionably shielded painting of Jackson Pollock, music of Arnold Schoenberg, or Jabberwocky verse of Lewis Carroll. ${ }^{153}$

In addition to the speech-conduct dichotomy, which has attracted scholarly attention, ${ }^{54}$ the Court has used another version of the ontological approach to the threshold question. This approach focuses upon the medium of communication chosen by the speaker, which triggers (or does not trigger) First Amendment protections depending on whether the medium is traditionally and familiarly considered to be one which implicates the First Amendment. ${ }^{55}$ Rather than receiving protection because of their content, these types of expression are favored because their medium is favored or, in other words,

50. United States v. O'Brien, 391 U.S. 367,376 (1968),

51. See Johnson, 491 U.S. at 404 (acknowledging that conduct "sufficiently imbued with elements of communication" may qualify for First Amendment protection) (quoting Spence, 418 U.S. at 409$)$.

52. 515 U.S. 557 (1995).

53. Id. at 569 (citations omitted).

54. See, e.g. EMERSON, supra note 46, at 16-17 (outlining important factors for gaining First Amendment protection); Ely, supra note 2, at 1491-96 (discussing the dichotomy in flag burning cases); Louis Henkin, The Supreme Court, 1967 Term-Foreword: On Drawing Lines, 82 Harv. L. REV, 63, 76-82 (1968) (discussing problems with the dichotomy); Melville B. Nimmer, The Meaning of Symbolic Speech Under the First Amendment, 21 UCLA L. REV. 29, 29-38 (1973) (discussing when conduct constitutes speech); Laurence R. Velvel, Freedom of Speech and the Draft Card Burning Cases, 16 U. KAN L. REV. 149, 149-62 (1968) (discussing the dichotomy in draft card burning cases).

55. Professor Tribe notes several "activities that have historically been recognized as incxtricably intertwined with speech or petition.... all of these activities might variously be described, without special illumination, either as 'speech' or as 'conduct,' but all must be recognized as activities of special first amendment significance." TRIBE, supra note 12, at 829-30. He includes in this list outdoor distribution of leaflets, door-to-door political canvassing, solicitation of contributions, mailbox-stuffing, picketing, civil rights demonstrations, boycotts, communicating with the government, and putting up outdoor posters and signs. See id. 
because they "reflect an exercise of these basic constitutional rights in their most pristine and classic form." 56

The medium-specific version of the ontological threshold analysis requires courts first to evaluate the medium through which the allegedly infringed speech is being transmitted. In Hurley, the Court began its analysis by noting that "[p]arades are thus a form of expression, not just motion." In Metromedia, Inc. v. San Diego, ${ }^{58}$ the Court highlighted the "uniqueness of each medium of expression" by noting that "[e]ach method of communicating ideas is a "law unto itself." 59 The idea here-at least with respect to the threshold analysis - is that there is a "list" of traditional or familiar mediums. This raises several important points.

First, the "list" of media given such favorable treatment has changed over time. ${ }^{60}$ Take the case of motion pictures. In 1915, the Court, in Mutual Film Corp. v. Industrial Commission ${ }^{61}$ rejected a challenge to an explicitly content-based licensing statute. The statute allowed only films of a "moral, educational or amusing and harmless character" to be approved. ${ }^{62}$ Noting first that films "may be used for evil," 63 the Court engaged in a bit of negative medium-specific analysis: Movies were "not to be regarded. nor intended to be regarded ... we think, as part of the press of the country or as organs of public opinion." 64 Twenty-seven years later, in Joseph Burstyn, (1963))

56. Hurley, 515 U.S. at 568-69 (quoting Edwards v. South Carolina, 372 U.S. 229, 235

57. Id. at 568 .

58. 453 U S. 490 (1981).

59. Id. at 501 \& n.8. It should, of course, be noted at the outset that the "frequent refrain" of medium-specificity is not unique to threshold analysis. Much of the "categorizing" of substantive First Amendment law is closely related to the medium in question. For example, the Court accords lower constitutional protection to speech conducted over the wireless broadcast medium. See Red Lion Broad. Co. v. FCC, 395 U.S. 367, 386-401 (1969) (upholding the fairness doctrine, which requires that public issues be presented by broadcasters and that each side should be given fair coverage). But the Court extends heightened protection to cable broadcasting, telephone, and the Internet. See Reno v. ACLU, 117 S. Ct. 2329, 2341-44 (1997) (holding content-based restrictions on the Internet unconstitutional); Turner Broad. Sys., Ine. v. FCC, 512 U.S, 622, 661-64 (1994) (requiring intermediate scrutiny for cable regulation); Sable Comm. v. FCC, 492 U.S. 115, 128, 131 (1989) (finding statutory ban on certain telephone messages unconstitutional). The importance of the medium in the ultimate substantive analysis further supports the proposition that in many cases the medium will be critical to the threshold determination as well.

60. Professor Post argues that a medium should be added to the list when the social conventions surrounding the medium create constitutionally meaningful relationships between the medium and ideas. See Post, supra note 13, at 1253-54. This is as sound a reason as any, though the Court is probably not that analytical about what is, by nature, a strikingly ad hoc proposition.

61. 236 U.S. 230 (1915)

62. Id. at 241 (quoting 1913 Ohio Laws 399).

63. Id. at 242 .

64. Id. at 244 . 
Inc. v. Wilson, ${ }^{65}$ the Court changed its tune and overruled Mutual Film. ${ }^{\circ 6}$ In Burstyn, the Court struck down a statute permitting the banning of "sacrilegious" movies on the grounds that "motion pictures are a significant medium for the communication of ideas." 6 ?

Second, the medium-specific approach can be as easily used to "downgrade" purported expression as to protect it. For example, courts do not consider the First Amendment to be implicated by "products" such as aeronautical charts. In Winter v. G.P. Putnam's Sons, ${ }^{68}$ the Ninth Circuit explained that aeronautical charts were in a special class of materials - a "medium," so to speak - that are more like physical products than books. ${ }^{69}$

Third, the medium-specific approach is as likely to be arbitrarily applied as the speech-conduct distinction. On the one hand, City of Dallas v. Stanglin ${ }^{70}$ tells us that "recreational dancing" is not a protected expressive activity. ${ }^{71}$ On the other, the plurality opinion in Barnes $v$. Glen Theatre, Inc. ${ }^{72}$ stated that nude barroom dancing is "within the outer perimeters of the First Amendment." 73 Clearly, there is ample room within the medium-specific framework for judicial value judgments. ${ }^{74}$ However, the essential failing of the medium-specific approach is that, by its very nature, it will protect only orthodox mediums of communication. "There's truth in the old saw that familiarity breeds contempt: nobody goes to Speakers' Corner to listen." $7 / 5$

65. 343 U.S. 495 (1952)

66. See id at 502 .

67. Id. at 497,501 .

68. 938 F.2d 1033 (9th Cir, 1991).

69. See id. at 1035-36. Significantly, the court included computer software in this product classification. See id at 1036; see also Brocklesby v. Jeppesen, 767 F.2d 1288, 1294-95 (9th Cir. 1985 ) (holding that aeronautical charts are products in product liability suits); Saloomey v. Jeppesen, 707 F.2d 671, 676-77 ( $2 \mathrm{~d} \mathrm{Cir}$. 1983) (holding that navigational charts are products); Post, supra note 13, at 1254 \& n.20 (explaining that courts in cases like Brocklesby do not think of the suits as raising First Amendment questions). It is not difficult to imagine how the argument might proceed for such charts. The cartographer would avow an intent to convey a message (perhaps the message of the safety and of the enjoyment of flying) and would attempt to show how the message is particularly developed. He or she would then argue, rather plausibly, that the consumers of the charts would be able to discern this message.

70. 490 U.S $19(1989)$.

71. See id. at $23-25$.

72. 501 U.S. 560 (1991).

73. Id. at 566 . Justice Souter justified this distinction because nude barroom dancing is "a performance directed to an actual or hypothetical audience." Id at 581 (Souter, J., concurring).

74. Cf. JOHN HART Ely, DEMOCRACY AND DistRUST: A THEORY OF JUdicial REVIEW 4448 (1980) (arguing that the judge's own values are often a source of constitutional judgment, but that such a practice is unacceptable).

75. Ely, supra note 2, at 1488-89. 
This mode of analysis will favor older, more established, and more litigated forms of communication - at the expense of new media. ${ }^{70}$

\section{B. Teleological Threshold Analysis}

In R.A.V. v. St. Paul ${ }^{77}$ the Court rejected any form of ontological threshold analysis when it struck down a statute criminalizing "bias-motivated" IIghting words. It noted instead that the dispositive (and sole) necessary analysis was that "[t]he First Amendment does not permit St. Paul to impose special prohibitions on those speakers who express views on disfavored subjects." 78 Thus, the Court explicated a second mode of threshold analysis, a teleological one, which is wholly separate from the activities of the speaker. ${ }^{79}$ This method asks whether the regulation is intended to suppress free expression. If it is not, the First Amendment is simply not implicated. Justice Scalia, concurring in the judgment in Barnes v. Glen Theatre, Inc., explicitly noted the procedural nature of the teleological inquiry:

76. Indeed, one must consider flag burning, if not draft card burning, parades, and music, to be recent additions to the "list" of media that implicate the First Amendment. It remains an open question whether the inevitable enlargement of the scope of the medium-specific threshold will render this mode of analysis useless.

77. 505 U.S. 377 (1992).

78. Id at 391 .

79. In the teleological mode of analysis, the threshold question is necessarily the primary question asked in a substantive balancing of the interests of the government and speaker. Therefore, courts using the teleological approach will, in effect, "compress" the analysis into two interrelated steps rather than three: The court first determines whether or not the regulation is related to free expression and then determines the level of scrutiny to be applied. See, e.g., id. at 391-96 (finding that an ordinance suppressing fighting words that provoke violence on the basis of race, color, creed, religion, or gender is content-based and facially unconstitutional).

This line of analysis is related to the doctrine of impermissible motives, where the "substantive motivation" test is primarily concerned with viewpoint discrimination. Sec, e.g., Cornelius v. NAACP Legal Defense \& Educ. Fund, Inc., 473 U.S. 788, 806-11 (1985) (noting the importance of motivation analysis while upholding an executive order limiting participation in a charity drive); Perry Education Ass'n v. Perry Local Educators' Ass'n, 460 U.S. 37, 50-55 (1983) (finding no evidence of viewpoint discrimination when scrutinizing a school board's choice to grant preferential access to the inter-school mail system to the union currently representing teachers); Consolidated Edison Co. v. Public Service Comm'n, 447 U.S. 530, 536 (1980) ("[W] then [the] regulation is based on the content of speech, governmental action must be scrutinized more carefully to ensure that communication has not been prohibited 'merely because public officials disapprove [of] the speaker's views.'") (citation omitted). See generally TRIBE, supra note 12, at 814-21 (considering facially neutral regulations motivated by content censorship); Paul Brest, Palmer v. Thompson: An Approach to the Problem of Unconstitutional Legislative Motive, 1971 SUP. CT. REV. 95 (arguing that courts should inquire into legislative motivations when they are ascertainable and when other grounds are not available); John Hart Ely, Legislative and Administrative Motivation in Constitutional Law, 79 YALE L.J. 1205 (1970) (defending the relevancy of legislative and administrative motivations in determining the constitutionality of government actions). 
All our holdings (though admittedly not some of our discussion) support the conclusion that "the only First Amendment analysis applicable to laws that do not directly or indireetly impede speech is the threshold inquiry of whether the purpose of the law is to suppress communication. If not, that is the end of the matter so far as the First Amendment guarantees are concerned; if so, the court then proceeds to determine whether there is substantial justification for the proscription." 80

Scalia stated that the Indiana statute was one of general applicability because it did not single out nude dancing, and thus convictions under the public indecency law were valid since the First Amendment was not implicated. ${ }^{81}$ "Indiana does not regulate dancing. It regulates public nudity." $\mathrm{\$ 2}$

Cohen v. Cowles Media Co. ${ }^{83}$ is another example of the teleological approach to threshold analysis. Rejecting a claim by a newspaper of First Amendment immunity from state promissory estoppel laws, the Court noted that the "Minnesota doctrine of promissory estoppel is a law of general applicability. It does not target or single out the press," 84 Thus, the First Amendment did not apply. ${ }^{85}$

While a strict teleological approach might be criticized for providing too little protection to speech, ${ }^{86}$ the evidence to date does not entirely support this view. At least five opinions have utilized the teleological threshold approach. In two, the threshold test triggered the protection of the First Amendment and the Court struck down the regulation at issue. ${ }^{87}$

More general criticisms of a purpose-based threshold test are similar to those enunciated against the substantive motivation analysis used in First

80. 501 U.S. 560, 578 (1991) (quoting Community for Creative Non-Violence v. Watt, 703 F.2d 586, 622-23 (D.C. Cir. 1983) (en banc) (Scalia, J., dissenting)).

31. See id. at 573-76. Justice Scalia drew support for this proposition from the Court's decisions relating to the free exercise of religion. See id. at 579 (citing Employment Div, Dep't. of Human Resources v. Smith, 494 U.S. 872 (1990) (holding that general laws not specifically targeted at religious practices did not require heightened First Amendment scrutiny even though they diminished some people's ability to practice their religion)).

82. Id. at 572-73 (quoting Miller v. Southbend, 904 F.2d 1081, 1120 (7th Cir. 1990)).

83. 501 U.S. 663 (1991).

84. Id. at 670 .

85. See id at 672 (holding that the First Amendment does not confer on the press a constitutional right to disregard promises that would otherwise be enforced under state law).

86. See, e.g., R.A.V. v. St. Paul, 505 U.S. 377, 426-28 (1992) (Stevens, J., concurring) (arguing that courts should consider the content and context of the speech).

87. See id at 391-93 (striking down, on First Amendment grounds, a statute criminalizing "bias-motivated" fighting words); United States v. Eichman, 496 U.S. 310, 315-19 (1990) (holding that the federal Flag Protection Act violated the First Amendment). 
Amendment viewpoint discrimination cases. ${ }^{88}$ In Palmer v. Thompson ${ }^{89}$ Justice Black outlined the basic objections to motivation analysis:

First, it is extremely difficult for a court to ascertain the motivation, or collection of different motivations, that lie behind a legislative enactment. . . It is difficult or impossible for any court to determine the "sole" or "dominant" motivation behind the choices of a group of legislators. Furthermore, there is an element of futility in a judicial attempt to invalidate a law because of the bad motives of its supporters. If the law is struck down for this reason, rather than because of its facial content or effect, it would presumably be valid as soon as the legislature or relevant governing body repassed it for different reasons. ${ }^{90}$

While the analysis of whether a particular enactment is intended to affect the communication of ideas may be more straightforward than discerning an impermissible motive in an otherwise permissible regulation, it cannot be questioned that this challenge will be significant. Indeed, as Professor Ely notes, "[I]t will be next to impossible for a court responsibly to conclude that a decision was affected by an unconstitutional motivation whenever it is possible to articulate a plausible legitimate explanation for the action taken." 1 But this is no reason not to undertake the inquiry - in fact, many regulations will not have an equally plausible alternative explanation. ${ }^{92}$ As such, teleological analyses seem equally likely to yield good results as any alternative.

\section{The Mistakes of Medium: The Present State of the LAW of SOFTWARE}

As of Fall 1998, three courts had analyzed the "law of software." These cases involved challenges to the constitutionality of federal export

88. See Gunther \& Sullivan, supra note 18 , at $751-52,1217$ (discussing the difficulty of assessing discriminatory motivation and determining legislative or administrative motivation).

89. 403 U.S. 217 (1971).

90. Id at 224-25 (citation omitted).

91. ELY, supra note 74 , at 138 .

92. For example, the law at issue in R.A.V, which proscribed the use of fighting words only when motivated by racial or religious bias, had few equally plausible explanations. "An ordinance not limited to the [dis]favored topics, for example, would have precisely the same beneficial effect." R.A.V., 505 U.S. at 396.

The Barnes law, on the other hand, is a much closer case. While the simple proscription of public nudity would appear to have less to do with speech and more to do with the social interest in order and morality, evidence that the state had not applied the statute to nudity as part of plays, ballets, or operas hints at a motive with First Amendment implications. See Barnes v. Glen Theatre, Inc., 501 U.S. 560, 590 (1991) (White, J., dissenting).

However, difficult factual scenarios do not obviate the discussion. The Barnes case would be equally difficult from a threshold perspective in either ontological approach.

93. See Junger v. Daley, 8 F. Supp. 2 d 708 (N.D. Ohio 1998); Karn v. United States Dep't of State, 925 F. Supp. 1 (D.D.C. 1996); Bernstein v. United States Dep't of State, 922 F. Supp. 1426 (N.D. Cal. 1996). 
controls on encryption software - specifically source code and object code. ${ }^{94}$ While the federal regulations ${ }^{95}$ do not restrict the export of software in written material, like books, they do restrict software exports in "machine readable" form. ${ }^{96}$

The first case to be decided was Karn v. United States Department of State. ${ }^{97}$ Karn challenged the restrictions on the international trade of his computer diskette containing cryptographic software samples, claiming that the regulatory scheme imposed by the Arms Export Control Act was an impermissible prior restraint on free speech. ${ }^{98}$ In considering the defendant's motion for summary judgment, the court made no explicit ruling on the threshold question, though it assumed for the purposes of the decision that the medium of source code may indeed trigger the protections of the First Amendment.99 Nonetheless, the court granted the summary judgment motion, holding that the government's rationale, not the form of speech or expression, controls the level of scrutiny. ${ }^{100}$ The court then applied the O'Brien

94. Source code is computer code understandable by humans. It is where the initial creation of the computer program takes place. In order to be understood ("run") by a computer, source code must be converted into object codc. This conversion is achieved by specialized computer programs known as compilers. These compilers take source code written in a specified language and convert (or "compile") it into object code. Typically, compilers are specifically designed for a particular processor, since most processors use slightly different patterns (or "instructions") to accomplish their tasks. Source code, on the other hand, is more versatile. As long as a compiler is available for a particular processor, the source code can be used to create a working program for that machine.

Digital object code is the fundamental language, or code, of the computer, and is the building block for all computer codes. At root, all computer processors operate using a series of $1 \mathrm{~s}$ and $0 \mathrm{~s}$. The patterns of $\mathrm{is}$ and $0 \mathrm{~s}$ in object code represent the alphanumeric characters used in the source code. The sequence and patterns of the $1 \mathrm{~s}$ and $0 \mathrm{~s}$ cause different responses from the computer. In general, object code cannot be read and understood by humans-it is the exclusive domain of the computer.

95. See Arms Export Control Act, 22 U.S.C. \& 2778 (1994 \& Supp. 1996) (authorizing the President to control the import and export of "defense articles"); International Traffic in Arms Regulations, 22 C.F.R. $\$ \$ 120-130$ (1998) (creating a procedure by which the State Department determines whether an item is covered by the Arms Export Control Act).

96. Given that the "written" software could be typed or scanned into computer-usable form, this distinction raises many questions. Apparently, the government is only interested in slowing down the international spread of encryption software, and deems that export via printed matter imposes enough obstacles to suit this purpose. See Karn, 925 F. Supp. at 10 (noting that machine readable media makes encoding by foreign intelligence sources much easier).

97. 925 F, Supp. 1.

98. See id. at 9. The software was also printed in the definitive book on cryptography, BRUCE SCHNEIER, APPLIED CRYPTOGRAPHY 623-73 (2d ed. 1996). The government did not object to the export of the book. See Karn, 925 F. Supp. at 3.

99. See id at 9-10.

100. See id. at 10 (explaining that if the regulation were content-specific it would be "presumptively invalid," but if it were content-neutral the government can justify the regulation if other criteria are met). 
test, and found the government interest to be unrelated to the suppression of free expression. ${ }^{101}$ The court let the restriction stand.

The Karn decision appears to have passed lightly over the threshold question and jumped immediately to substantive analysis using the O'Brien test. By moving straight to the analysis of the regulation, the Karn court found it unnecessary to resolve the status of software code under the First Amendment. ${ }^{102}$ Under $R, A, V$ and $O^{\prime} B r i e n$, the court noted, the government's rationale for the restriction is determinative. ${ }^{103}$ The best reading of the case, then, is that the court used a teleological threshold test in place of the assumed-away ontological test. By focusing squarely upon the intent and reach of the governmental action, the court thus avoided the fallacies of the ontological, medium-specific threshold analysis. ${ }^{104}$

The Bernstein v. United States Department of State ${ }^{105}$ decision is not so successful at avoiding such fallacies. While the basic fact pattern is quite similar to Karn, ${ }^{106}$ the Bernstein court explicitly ruled that source code is speech for the purposes of the First Amendment, ${ }^{107}$ noting that "Bernstein's encryption system is written, albeit in computer language rather than in English." 108 The court's analysis is plagued by several fundamental fallacies.

First, the Bernstein court's rush to formalism on the threshold question effectively disconnects the rationale for the decision from the support of First

101. The court held:

The defendants are not regulating the export of the diskette becausc of the expressive content of the comments and or source code, but instead are regulating because of the beliet that the combination of encryption source code on machine readable media will make it easier for foreign intelligence sources to encode their communications.

Id. at 10 .

102. See id. at 10 ("Accordingly, it is unnecessary for the Court to make any finding regarding the nature of the [purported speech].").

103. See id. This is markedly similar to the Supreme Court's approach in O'Brien itself, where it assumed away the speech-conduct question to focus on the regulation at issue. See United States v. O'Brien, 391 U.S. 367, $376-77$ (1968) (stating that even if burning a draft card triggered the First Amendment, the conduct would not be constitutionally protected if the regulation reflects a legitimate government interest).

104. Admittedly the court avoided this in part because it simply assumed, without deciding, that software is speech. See Karn, $925 \mathrm{~F}$. Supp. at 9-10.

105. 922 F. Supp. 1426 (N.D. Cal. 1996). As of the date this article went to press, Bernstein was pending (after argument) on appeal to the Ninth Circuit. While the ultimate outcome of Bernstein may provide further clarity for the law of software described in this article, it does not affect the more general argument that the lower court's formalistic analysis is deeply flawed.

I06. Bernstein, a graduate student at U.C. Berkeley at the time of the 1995 filing (he is now a professor), wanted to publish his own encryption software program, Snuffle, over the Internet and share the software with colleagues overseas. He filed suit after the State Department denied his request. See id. at 1429-30.

107. See id. at $1434-36,1439$.

108. Id at 1434-35. 
Amendment values. The First Amendment is not about the canonizationvia constitutional status - of what can be printed out on paper, but about preventing the government from proscribing expression-regardless of formbecause of disapproval of the ideas expressed. ${ }^{109}$ Focusing on formalistic categories such as the written and spoken word is not only inconsistent with the core values of the First Amendment, but may also result in the limiting of other forms of expression, especially new media technologies.

Second, the court applied a medium-specific threshold test, but greatly abstracted the selection of the medium. The court reasoned that because software is recorded by means of language, it is therefore "written word." 10 And while few would contend that the "written word" is not a traditionally protected medium of expression sufficient to trigger the First Amendment, "11 the selection of "written word" rather than "source code" or "software" as the appropriate analytic medium begs the question. Given a sufficient level of abstraction, many things might look like the "written word." More to the point, however, is the converse: Given an increasing level of abstraction, many "traditionally" protected modes of expression begin to lose their clarity. The parades in Hurley begin to look like gatherings, walks, or even simply generalized conduct. Flag burning and dancing would blur into more generalized conduct, and music would look a lot like noise. ${ }^{112}$ This level of abstraction sidestep around difficult issues works both ways, of course, ${ }^{113}$ and the losses might be greater than the gains. ${ }^{114}$

109. See, e.g., R.A.V. v. St. Paul, 505 U.S. 377, 382 (1992) ("The First Amendment generally prevents government from proscribing speech or even expressive conduct because of disapproval of the ideas expressed.") (citations omitted); Texas v. Johnson, 491 U.S. 397, 414 (1989) (stating that the key principle underlying the First Amendment is that the government may not prohibit the expression of an idea simply because society finds the idea offensive).

110. Bernstein, 922 F. Supp. at 1434-35.

111. Cf. Minneapolis Star \& Tribune Co. v. Minnesota Comm'r of Revenue, 460 U.S. 575 , 583-85 (1983) (noting the high level of First Amendment protection given to the press).

112. See Ward v. Rock Against Racism, 49I U.S. 781, 790 (1989) (drawing a distinction between regulating noise and regulating music).

113. To be fair, the relatively thin Supreme Court doctrine regarding the medium-specific analysis teaches little about the level of abstraction issue. But the contours of a possible resolution might be discerned. In Hurley, the Court probably chose to define the activity as marches or parades rather than walking or gatherings because the challenged statutory action was directed at parades. The parade had regulatory significance - it was the nexus of the dispute and the locus of the purported expression. See Hurley v Irish-American Gay, Lesbian and Bisexual Group, 515 U.S $557,568-69$ (1995). A reasonable standard for the proper level of abstraction may therefore be the level which has regulatory significance. In Bernstein, the regulation targeted cryptographic software (or object code and source code). See Bernstein, 922 F. Supp. at 1429; International Traffic in Arms Regulations, 22 C.F.R. \$ 121.1 XIII(b)(1) (1998). That is where the impacted mode of communication lies.

114. Indeed, it is interesting to note that the effect of basing the threshold test upon the medium of the "written word" is such that the case does not end up lending much support to the propo- 
Finally, the Bernstein court attempted to support the proposition that software is speech by noting that since much computer software is subject to protection under the Copyright Act as a "literary work," 115 and copyright law protects "expression," then software must be expression. ${ }^{116}$ While this statement has some formalistic appeal (surely the term "expression" must be consistent across different legal disciplines?), further investigation undercuts its logic. First, the scope of copyright protection is statutory, not constitutional. ${ }^{117}$ Second, in many ways, copyright law is a curtailment of free expression, closely skirting the First Amendment. ${ }^{118}$ Thus, there is no reason to think that the conceptions of "expression" are similar, much less coextensive. Third, in order to reconcile the apparent conflict, copyright doctrine specifically excludes ideas from protection. ${ }^{119}$ The copyrightable remaining work is known as the expression. ${ }^{120}$ In stark contrast, ideas are fundamental to the First Amendment conception of expression.121 Therefore, the term "expression" cannot be interchanged between copyright and First Amendment doctrine, and locating the penumbra of First Amendment protections by refer-

sition that software is speech, since the court's logical reasoning extends only as far as the uncontroversial argument that the written word triggers the First Amendment.

115. Copyright Act of 1976, 17 U.S.C. $\$ \$ 101,102($ a)(1) (1994); accord Apple Computer, Inc. v. Franklin Computer Corp., 714 F.2d 1240, 1249 (3d Cir. 1983) ("Thus a computer program. whether in object code or source code, is a 'literary work' .... .").

116. See Bernstein, 922 F. Supp. at 1436.

117. See Paul Goldstein, Copyright, Patent, Trademark and Related State DOCTRINES 552-53 (1997) (discussing the nature and origin of United States copyright law).

118. See generally Paul Goldstein, Copyright and the First Amendment, 70 COLUM. L. REV. 983 (1970) (discussing the conflict between copyright law and the First Amendment); Melville B. Nimmer, Does Copyright Abridge First Amendment Guarantees of Free Speech and Press?, 17 UCLA L. REV. 1180 (1970) (discussing policy considerations related to a balance of free speech and copyright interests). Nonetheless, these commentators note that copyright's incentives for free expression may enhance the free exchange of ideas. See Goldstein, supra at 990-91 (noting that the economic incentive of copyright theoretically ensures a wide range of creative subject matter); Nimmer, supra at 1186 (stating that copyright law is based on the idea that monopoly is a necessary stimulus to the full realization of creative activities).

119. The idea-expression dichotomy is codified in 17 U.S.C. \$ 102(b) (1994) ("In no case does copyright protection for an original work of authorship extend to any idea ....".). See Sid \& Marty Krofft Television Prod., Inc. v. McDonald's Corp., 562 F.2d 1157, 1170 (9th Cir. 1977) ("[T]he idea-expression dichotomy already serves to accommodate the competing interests of copyright and the first amendment."); see also Fantasy, Inc. v. Fogerty, 664 F. Supp. 1345, 1351 (N.D. Cal. 1987) (citing Sid \& Marty, 562 F.2d at 1170).

120. See Sid \& Marty, 562 F.2d at 1163 ("It is an axiom of copyright law that the protection granted to a copyrighted work extends only to the particular expression of the idea and never to the idea itself.").

121. See, e.g., Cohen v. California, 403 U.S. 15, 26 (1971) (stating that expression "conveys not only ideas capable of relatively precise, detached explication, but otherwise inexpressible emotions as well"); Whitney v. California, 274 U.S. 357, 375 (1927) ("[F]reedom to think as you will and to speak as you think are means indispensable to the discovery and spread of ...truth.") (Brandeis, J., concurring). 
ence to those protections of the Copyright Act is profoundly inappropriate. ${ }^{122}$ Whether a particular software product may be protected under the Copyright Act is simply not relevant to First Amendment analysis.

The court in Junger $v$. Daley ${ }^{123}$ steered an approximate middle path between the Kam and Bernstein decisions. Holding that "although encryption source code may occasionally be expressive, its export is not protected conduct under the First Amendment," 124 the Junger court performed a two-tier ontological analysis: first, a medium-based analysis of encryption source code; and second, a speech-conduct analysis of the exporter's activities. While at first glance this bifurcated ontological analysis may seem promising, a closer look exposes a familiar set of weaknesses.

Initially, the court's medium-based analysis assumed a seemingly limitless number of mediums within the "medium" of software code: "Certain software is inherently expressive.... other software is inherently functional."125 Finding source code for encryption software to be especially functional rather than expressive, the court noted that "[m]ore than describing encryption, the software carries out the function of encryption.... In doing this function, the encryption software is indistinguishable from dedicated computer hardware that does encryption." 126

The parsing of the "medium" of software code does little to improve the failing of medium-based analyses. ${ }^{127}$ First, the opinion continues to condition First Amendment protection on the choice of medium. ${ }^{128}$ To the Junger court, choices within the software genre will determine the outcome rather than the choice of software as a medium of expression. This is no less troublesome than a broader categorization, of course: Decisions "approving" certain forms of software code as First Amendment mediums will still underprotect new, unlitigated forms. ${ }^{129}$

In distinguishing among apparent sub-mediums in software code, the Junger court pointed to the functional identity between encrypted source

122. There is another, perhaps as damaging, argument against the use of copyright analogies in this context: It plays straight into the hands of the "functional" argument. That is, the so-called "useful articles" exception to copyright law, codified in 17 U.S.C. \& 101 (1994 \& Supp. 1996), limits the scope of copyright protection to pictorial, graphic, and other visual works by excluding useful aspects of the work. See Brandir Int'I, Inc. v. Cascade Pac. Lumber Co., 834 F,2d 1142, 1143 (2d Cir. 1987) (discussing this limitation).

123. 8 F. Supp. 2d 708 (N.D. Ohio 1998).

124. Id at 715 .

125. Id at 716 .

126. Id.

127. See notes 54-76 supra and accompanying text.

128. See Junger, 8 F. Supp. 2 d at 716 ("In reviewing governmental regulation of computer software, the Court need examine the software involved,").

129. See notes $75-76$ supra and accompanying text. 
code and dedicated computer hardware. ${ }^{130}$ This, of course, is not particularly helpful; software code, by definition, performs the function of instructing computer hardware to act. The more important (and interesting) part of this analysis is that the court based its decision in part on the results of the source code - that is, the acts that the software seeks to have the hardware perform. The court seemed to say that because encryption code is not protected by the First Amendment, the software that "carries out the function of encryption" does not receive uniform protection. ${ }^{131}$ Significantly, the focus on results implicitly removes the "medium" question to a form of conduct analysis. That is, the issue becomes whether the results of the software code are expressive or simply functional.

However, comparing expression versus functionality for software is no less difficult than measuring speech versus conduct for human behavior. ${ }^{132}$ A software-hardware combination that performs encryption is quite likely to be both expression and function - both the act of encrypting and a statement about encryption policy. Again, the undifferentiated whole..$^{133}$

After determining that encryption source code is tarely expressive, the Junger court moved to a more traditional speech-conduct analysis of the act of exporting encryption source code. Applying Spence, the court determined that the export of source code does not convey an unmistakable message, ostensibly because the code itself is not sufficiently expressive. ${ }^{134}$ This, of course, is ontology upon ontology. In essence, the Junger opinion concludes that because the purported speaker chose an unexpressive medium of communication, transmitting the purported expression cannot be speech. The choice of medium is again dispositive; the speech-conduct outcome is predetermined.

In the end, Junger upheld the export regulations for reasons as questionable as the Bernstein court's opposite conclusion. ${ }^{135}$ Although the court recognized the fallacy of Bernstein's "speech is writing" analysis, ${ }^{136}$ and focused instead on the functionality of the medium of source code, this func-tionality determination - as merely a different form of medium-based analysis - is little better than the misguided formalism used by the Bernstein court.

130. See Junger, 8 F. Supp. $2 \mathrm{~d}$ at 716.

131. Id.

132. See notes 41-53 supra and accompanying text.

133. See Ely, supra note 2, at 1495.

134. See Junger, 8 F. Supp. 2d at 717-18 ("Because the expressive elements of encryption source code are neither 'unmistakable' nor 'overwhelmingly apparent' its export is not protected conduct under the First Amendment.") (citing Tinker v. Des Moines Indep. Community Sch. Dist., 393 U.S. 503, 505-06 (1969) and Texas v. Johnson, 491 U.S. 397, 406 (1989)).

135. See notes 105-122 supra and accompanying text.

136. See note 108 supra and accompanying text. 
Neither the Karn nor the Bernstein case directly addressed the application of computer software to the other ontological mode of threshold analysis: the speech-conduct distinction. ${ }^{137}$ As noted above, the speech-conduct distinetion rests upon the fallacy that the expressive elements in any action can be separated from the conduct. ${ }^{138}$ As Junger amply demonstrates, there is no reason to believe that software will have any special immunity from this problem. Indeed, if there ever was conduct that was an "undifferentiated whole" of action and expression, the use and operation of computer code would seem to be it. ${ }^{139}$ The hypothetical programmer Debra is both acting and expressing when she releases Lucifer onto the Internet; trying to separate the two elements of her activity would be no easier than it would for the burning of draft cards. ${ }^{140}$

The analysis of software under the speech-conduct distinction is problematic because computer code is primarily, perhaps even exclusively, functional. This inherent, and possibly overwhelming, functional aspect serves to undermine a speaker's claim that the development or use of computer software is intended to convey a particularized message. If Johnson had been burning his flag for warmth, or O'Brien using his draft card to start his barbecue, the Court would have been hard-pressed to find sufficient elements of expression to warrant First Amendment protection. The Bernstein court dismissed this argument as "immaterial," comparing computer software to recipes, instructions, and do-it-yourself manuals, which it noted are also speech. ${ }^{141}$ But the analogies don't fit. Each of these examples is itself used to communicate information between people; software, to the extent it can be considered a set of instructions, communicates only to machines. While it is true that there is no exception to the First Amendment for useful speech, ${ }^{1+2}$ this argument presupposes the existence of speech. After all, the First Amendment does not protect products. ${ }^{143}$

137. The government's primary contention in Bernstein appears to have been that software itself was conduct rather than speech, and could thus be regulated. See Bernstein v. United States Dep't of State, 922 F. Supp. 1426, 1434 (N.D. Cal. 1996). As I demonstrate below, this was not the most helpful approach.

138. See notes $42-50$ supra and accompanying text.

139. This statement sets aside the obvious distinction between the actual software code (source or object) and the comments, if any, inserted into the source code to make it more readable for humans. Comments, which add nothing to the operation or function of the software, would be folly protected by the First Amendment irrespective of the status of the software itself.

140. See United States v. O'Brien, 391 U.S. 367, 376 (1968) (refusing to decide definitively if O'Brien's actions could constitute speech).

141. See Bernstein, 922 F. Supp. at 1435.

142. See id.

143. See Winter v. G.P. Putnam's Sons, 938 F.2d 1033, 1036 (9th Cir. 1991) (contrasting, for First Amendment purposes, "products," such as aeronautical charts, with "ideas and expression in a book"). 


\section{THE BEST LAW OF SOFTWARE IS NO LAW OF SOFTWARE}

As this note has demonstrated, the "law of software" is still unsettled. The three cases that have addressed the issue are split in their ultimate holdings as far as the First Amendment status of source code. These decisions are undercut by a series of fallacies and misunderstandings. The wildly divergent holdings and troublesome analyses of Bernstein and Junger demonstrate that the already weakened ontological approach to First Amendment analysis cannot support the weight of new mediums of communication, and that software is not-and should not be-"a law unto itself."

The teleological mode of analysis is a more analytically sound method for evaluating the scope of First Amendment protection for software. This method, of course, tells us nothing about the protection given to the medium of computer software, except that software will receive neither favorable nor unfavorable treatment. Furthermore, a teleological method of analysis will neither hinder nor help software's status as a developing technology. By not according special constitutional status to different forms or types of software, the law avoids distorting the market for software and related technologies.

However attractive it might be in the abstract to develop a "law of software"- to perhaps once and for all put software beyond the scope of government regulators - careful analysis reveals that the best law of software is no law of software. Technology inexorably develops; we simply cannot know how it will change our world or why. But we can be sure that software is far from the last new mode of communications to come down the pike. Therefore, as the Court clearly stated in Denver Area Educational Telecommunications Consortium, Inc. v. FCC: ${ }^{145}$

" $[\mathrm{N}]$ o definitive choice among competing analogies ... allows us to declare a rigid single standard, good for now and for all future media and purposes.... Rather, aware as we are of the changes taking place in the law, the technology, and the industrial structure, related to [this industry], we believe it unwise and unnecessary definitely to pick one analogy or one specific set of words now:"146

In the context of computer software, focusing on the medium would be the mistake.

144. Metromedia, Inc. v. San Diego, 453 U.S. 490, 501 (1981).

145. 116 S. Ct. 2374 (1996).

146. Id. at 2385 (citations omitted). 